\title{
Treatment Approaches in 102 Elderly Patients With Non- Small Cell Lung Cancer
}

\author{
Sener Cihan ${ }^{\mathrm{a}, \mathrm{e}}$, Hatice Odabas ${ }^{\mathrm{b}}$, Nuriye Yildirim Ozdemir ${ }^{\mathrm{c}}$, Dogan Yazilitas ${ }^{\mathrm{c}}$, Nalan Akgul Babacan ${ }^{\mathrm{d}}$
}

\begin{abstract}
Background: The life expectancy and presence of co-morbidities cause reservations in treatment decisions for elderly patients with cancer. In this study, we retrospectively evaluated 102 patients who are considered as middle-old aged (aged $75-84$ ) by gerontologists.

Methods: Medical records of patients were reviewed. One hundred and two patients with a diagnosis of non-small cell lung cancer (NSCLC) whose follow-up ended with death between March 2006 and May 2013 were examined.
\end{abstract}

Results: The median age at diagnosis was 77 (75 - 85) years. Thirtythree patients $(67.6 \%)$ were over 80 years old. The number of patients with metastasis was $57(55.8 \%)$. Forty-two (41.2\%) patients had stage IIIA and IIIB disease. Fifteen of the metastatic patients $(26.3 \%)$ were given chemotherapy, while 12 of the non-metastatic patients (26.6\%) were given chemotherapy. Of the non-metastatic patients, 25 $(55.6 \%)$ were treated with radiotherapy, and five $(11.1 \%)$ were treated with chemotherapy. The median duration of follow-up was 4 (1-55) months. Progression-free survival (PFS) was 4 months in non-metastatic patients, and 3 months in metastatic patients. Overall survival (OS) was 4 months. OS rates for 1 and 2 years were $10 \%$ and $2 \%$.

Conclusion: Chemotherapy and radiotherapy may be administered even to patients of this age group. The beneficial effect of chemotherapy in patients with metastasis on OS is an important finding of our study.

Keywords: Middle-old patient; Non-small lung cancer; Treatment;

Manuscript accepted for publication February 24, 2015

aDepartment of Medical Oncology, Okmeydani Training and Research Hospital, 34100 Sisli, Istanbul, Turkey

bDepartment of Medical Oncology, Dr. Lutfi Kirdar Kartal Education and Research Hospital, 34860 Kartal, Istanbul, Turkey

'Department of Medical Oncology, Ankara Numune Training and Research Hospital, 06100 Altindag, Ankara, Turkey

${ }^{\mathrm{d}}$ Department of Medical Oncology, Marmara University Pendik Education and Research Hospital, 34860 Kartal, Istanbul, Turkey

${ }^{e}$ Corresponding Author: Sener Cihan, Department of Medical Oncology, Okmeydani Training and Research Hospital, 34100 Istanbul, Turkey.

Email: drsenercihan@yahoo.com
Survival

\section{Introduction}

The risk of cancer increases with aging. The median age of lung cancer patients is 70 and thus it is a type of cancer that is more often seen in the elderly [1]. In the USA, $47 \%$ of all patients with non-small cell lung cancer (NSCLC) are in the age group of 70 years and older. Of 1,200,000 patients with NSCLC worldwide, 300,000 are over 70 years of age [2,3]. Multi-organ failure, multiple drug use, and a decrease in the functional reserve of organs such as bone marrow are seen with aging. This makes cancer treatment more important and difficult in the elderly. Only a quarter of the patients with NSCLC at the age of 65 years and older could be given chemotherapy in the study by Earle et al [4]. Life expectancy in the elderly and side effects of treatments are important factors in cancer therapy. Although ECOG performance scoring may be used to show the performance in many cases, activities of daily living (ADL) and instrumental activities of daily living (IADL) performance systems are more convenient in the elderly [5]. The comprehensive geriatric assessment (CGA) is another scoring system used in chemotherapy or palliative therapy of elderly patients [6-9].

Cisplatin-based chemotherapeutic regimens are accepted generally for younger patients [10]. There are many studies in the literature on chemotherapy in elderly patients and on therapeutic regimens [11-16].

Chronologically, old is considered as an age of 65 years and over. The World Health Organization has defined the psychogeriatric aging as "old" for those at an age of 65 years and over, and "very old" for those at an age of 85 and over. On the other hand, according to the classification of gerontologists, those between 65 and 74 years are defined as young-old aged, those between 75 and 84 years are middle-old aged and those over 85 years are defined as the oldest-old $[17,18]$. We present here a retrospective evaluation of 102 patients in the middleold age (aged 75 - 84) with NSCLC.

\section{Methods}

Medical records of patients followed up at two different on- 
Table 1. Patient Characteristics

\begin{tabular}{|c|c|c|c|c|}
\hline Characteristics & No treatment group, n (\%) & Treatment group, n (\%) & P value & Total, n (\%) \\
\hline Median age (min - $\max )$ & $78(75-85)$ & $76(75-85)$ & 0.36 & $77(75-85)$ \\
\hline Gender & & & 0.41 & \\
\hline Male & $53(94.6)$ & $45(97.8)$ & & $98(96.1)$ \\
\hline Female & $3(5.4)$ & $1(2.2)$ & & $4(3.9)$ \\
\hline Age & & & 0.42 & \\
\hline$<80$ & $36(64.3)$ & $33(71.7)$ & & $69(67.6)$ \\
\hline$>80$ & $20(35.7)$ & $13(28.3)$ & & $33(32.4)$ \\
\hline Surgery & & & 0.53 & \\
\hline None & $55(98.2)$ & $44(95.6)$ & & $99(97)$ \\
\hline Lobectomy & $1(1.8)$ & $1(2.2)$ & & $2(2)$ \\
\hline Pneumonectomy & 0 & $1(2.2)$ & & $1(1)$ \\
\hline \multicolumn{5}{|l|}{ Histological type } \\
\hline Adenocancer & $15(26.8)$ & $5(10.8)$ & 0.048 & $20(19.6)$ \\
\hline Squamous cancer & $27(48.2)$ & $31(67.4)$ & & $58(56.9)$ \\
\hline Unknown & $14(25)$ & $10(21.8)$ & & $24(23.5)$ \\
\hline \multicolumn{5}{|l|}{ Hemoglobin in diagnosis } \\
\hline$<10$ & $19(33.9)$ & $7(15.2)$ & 0.003 & $26(25.5)$ \\
\hline$>10$ & $37(66.1)$ & $39(84.8)$ & & $76(74.5)$ \\
\hline \multicolumn{5}{|l|}{ Baseline co-morbidities } \\
\hline Hypertension & $13(23.2)$ & $13(28.3)$ & 0.005 & $26(25.5)$ \\
\hline Cardiac co-morbidities & $14(25)$ & $11(23.9)$ & & $25(24.5)$ \\
\hline Pulmonary co-morbidities & $6(10.7)$ & $4(8.7)$ & & $10(9.8)$ \\
\hline Diabetes mellitus & $2(3.6)$ & $10(21.8)$ & & $12(11.8)$ \\
\hline$\geq 3$ co-morbidities & $15(26.8)$ & $2(4.3)$ & & $17(16.7)$ \\
\hline \multicolumn{5}{|l|}{ ECOG performance status } \\
\hline 0 & $2(3.6)$ & $3(6.5)$ & $<0.001$ & $5(4.9)$ \\
\hline 1 & $4(7.2)$ & $21(45.6)$ & & $25(24.5)$ \\
\hline 2 & $13(23.2)$ & $13(28.3)$ & & $26(25.5)$ \\
\hline$\geq 3$ & $37(66)$ & $9(19.6)$ & & $46(45.1)$ \\
\hline \multicolumn{5}{|l|}{ Stage } \\
\hline 1 & 0 & $2(4.3)$ & $<0.001$ & $2(2)$ \\
\hline 2 & $1(1.8)$ & 0 & & $1(1)$ \\
\hline $3 \mathrm{~A}$ & $3(5.4)$ & $8(17.4)$ & & $11(10.8)$ \\
\hline $3 \mathrm{~B}$ & $10(17.8)$ & $21(45.6)$ & & $31(30.4)$ \\
\hline 4 & $42(75)$ & $15(32.7)$ & & $57(55.8)$ \\
\hline \multicolumn{5}{|l|}{ Metastasis site } \\
\hline Brain & $6(10.7)$ & $2(4.3)$ & 0.003 & $8(14)$ \\
\hline Adrenal glands & $1(1.8)$ & $1(2.2)$ & & $2(3.5)$ \\
\hline Bone & $4(7.2)$ & $5(10.9)$ & & $9(15.8)$ \\
\hline Contralateral lung & $10(17.8)$ & $3(6.5)$ & & $13(22.8)$ \\
\hline Multiple metastasis & $21(37.5)$ & $4(8.7)$ & & $25(43.9)$ \\
\hline \multicolumn{5}{|l|}{ Treated with chemotherapy } \\
\hline Metastatic disease & $\mathrm{N}$ & $\mathrm{N}$ & & $15(26.3)$ \\
\hline Locally advanced disease & & & & $12(26.6)$ \\
\hline No & & & & $73(71.6)$ \\
\hline \multicolumn{5}{|l|}{ Treated with radiotherapy } \\
\hline Radiotherapy & $\mathrm{N}$ & $\mathrm{N}$ & & $25(55.6)$ \\
\hline Chemoradiotherapy & & & & $5(11.1)$ \\
\hline Palliative radiotherapy & & & & $39(68.2)$ \\
\hline
\end{tabular}


Table 2. Chemotherapy Regimens Used in Metastatic and Non-Metastatic Setting

\begin{tabular}{|c|c|c|c|}
\hline \multirow{2}{*}{ Chemotherapy regimens } & \multicolumn{2}{|c|}{ Number of patients, $n(\%)$} & \multirow{2}{*}{ Explanation } \\
\hline & Non-metastatic & Metastatic & \\
\hline Gemcitabine/cisplatin & $2(16.7)$ & $6(40)$ & $\begin{array}{l}\text { Gemcitabine } 1,000 \mathrm{mg} / \mathrm{m}^{2} \text { day } 1 \text { and } 8 \text {; cisplatin } 60 \mathrm{mg} / \mathrm{m}^{2} \\
\text { day } 1 \text { every } 21 \text { days }\end{array}$ \\
\hline Docetaxel/cisplatin & $1(8.3)$ & $3(20)$ & $\begin{array}{l}\text { Docetaxel } 60 \mathrm{mg} / \mathrm{m}^{2} \text { day } 1 \text {; cisplatin } 60 \mathrm{mg} / \mathrm{m}^{2} \text { day } 1 \text { every } \\
21 \text { days }\end{array}$ \\
\hline Gemcitabine/carboplatin & $2(16.7)$ & $1(6.7)$ & $\begin{array}{l}\text { Gemcitabine } 1,000 \mathrm{mg} / \mathrm{m}^{2} \text { day } 1 \text { and } 8 \text {; carboplatin AUC } \\
4 \text { day } 1 \text { every } 21 \text { days }\end{array}$ \\
\hline Docetaxel/carboplatin & $1(8.3)$ & $2(13.3)$ & $\begin{array}{l}\text { Docetaxel } 60 \mathrm{mg} / \mathrm{m}^{2} \text { day } 1 \text {; carboplatin AUC } 4 \text { day } 1 \text { every } \\
21 \text { days }\end{array}$ \\
\hline Vinorelbine/cisplatin & $1(8.3)$ & $2(13.3)$ & $\begin{array}{l}\text { Vinorelbine } 25 \mathrm{mg} / \mathrm{m}^{2} \text { day } 1 \text { and } 8 \text {; cisplatin } 60 \mathrm{mg} / \mathrm{m}^{2} \text { day } 1 \\
\text { every } 21 \text { days }\end{array}$ \\
\hline Vinorelbine & $1(8.3)$ & $1(6.7)$ & $\begin{array}{l}\text { Vinorelbine } 25 \mathrm{mg} / \mathrm{m}^{2} \mathrm{IV} \text { first day and } 60-80 \mathrm{mg} / \mathrm{m}^{2} \text { oral } \\
\text { day } 1 \text { and } 8 \text { every } 21 \text { days }\end{array}$ \\
\hline
\end{tabular}

cology centers were reviewed. A total of 102 patients with NSCLC who were followed up between March 2006 and May 2013, and had eventually died were examined.

Survival measures were progression-free survival (PFS) and overall survival (OS), as most of the patients were stage III and stage IV. PFS was determined as time to local recurrence, metastasis, death without progression of disease or last control from diagnosis. OS was determined as time to death or last control. Both of these were calculated as the mean number of months. Statistical analyses were done with Statistical Package for Social Sciences (SPSS 20.0) software. Survival analyses were done according to the Kaplan-Meier method, and Fisher's exact test and Chi-square tests were used to evaluate nominal variables and numeric data.

\section{Results}

Clinical and pathological characteristics of patients are summarized in Table 1. The median age at diagnosis was 77 (75 - 85) years. Thirty-three patients $(67.6 \%)$ were over 80 years. Although stage IV disease was more prevalent in both groups, the difference was not statistically significant $(\mathrm{P}=0.77)$. Only four $(3.9 \%)$ of the patients were females. All female patients had the adenocarcinoma subtype with bone-metastatic stage IV disease. Sixteen (88.9\%) patients with a hemoglobin value below $10 \mathrm{mg} / \mathrm{dL}$ at diagnosis had stage IV disease and this finding was statistically significant $(\mathrm{P}=0.02)$.

Low hemoglobin value was found to be a factor with an effect on OS $(\mathrm{P}<0.001)$. Only three patients $(2.9 \%)$ were treated surgically (one pneumonectomy and two lobectomies). The patient who had undergone pneumonectomy was 75 years old and had stage IIIA disease. Four courses of adjuvant cisplatin/etoposide were administered and the patient survived for 28 months, which is considerably longer than OS. In the pathological subtyping, 20 patients (19.6\%) had adenocancer, $58(56.9 \%)$ had squamous cell carcinoma, whereas subtyping could not be done in 24 patients $(23.5 \%)$. A significant effect of the pathological subtypes on PFS $(\mathrm{P}=0.99)$ and OS $(\mathrm{P}=0.59)$ was not detected. A total of 88 patients $(86.3 \%)$ had inoperable disease, with stage IIIB disease in 31 patients $(30.4 \%)$ and stage IV disease in 57 patients $(55.8 \%)$. Patients with multiple metastases, including to the brain, had a shorter OS (median 2 months), while the best OS was detected in patients with contralateral lung metastasis or bone metastasis (median 6 months).

Chemotherapy was administered to $15(26.3 \%)$ of the metastatic patients, while $39(68.2 \%)$ were administered palliative radiotherapy. There was a statistically significant OS difference between metastatic patients who were administered chemotherapy, with an OS median of 6 months (95\% CI: 4.1 - 7.9 months) and patients who were not administered chemotherapy, with an OS median of 3 months (95\% CI: $2.3-3.7$ months) $(\mathrm{P}=0.02)$. Twelve of the patients with non-metastatic disease $(26.6 \%)$ were administered only chemotherapy, while five $(11.1 \%)$ were administered chemoradiotherapy and $25(55.6 \%)$ only radiotherapy. The worst survival was in the chemoradiotherapy arm, with a median of 4 months, while survival had a median of 9 months in the radiotherapy arm and a median of 10 months in the chemotherapy arm. But these values were not statistically significant $(\mathrm{P}=0.53)$. In the comparison of the group which was administered one of these three treatment modalities and those who did not receive any treatment in the non-metastatic patient group, the OS in patients who were treated was better, with a median of 8 months $(95 \%$ CI: 5.1 - 10.9) compared to a median of 4 months without treatment (95\% CI: 1.4 - 6.6). But this difference did not reach statistical significance $(\mathrm{P}=0.12)$.

Dual combination chemotherapy regimens were used in both metastatic and non-metastatic patient groups (Table 2). 
Table 3. $P$ values of Prognostic Factors

\begin{tabular}{lll}
\hline \multirow{2}{*}{ Factor } & \multicolumn{2}{c}{ Pvalue } \\
\cline { 2 - 3 } & Progression-free survival & Overall survival \\
\hline Gender & 0.802 & 0.635 \\
Hemoglobin & 0.903 & $<0.001$ \\
Pathology & 0.986 & 0.592 \\
LVI & 0.031 & 0.135 \\
Perineural invasion & 0.072 & 0.342 \\
Stage & 0.515 & $<0.001$ \\
Metastatic site & 0.032 & $<0.001$ \\
Receiving chemotherapy & 0.094 & 0.021 \\
Receiving treatment & 0.671 & 0.534 \\
\hline
\end{tabular}

The gemcitabine/cisplatin combination was the most frequently used combination in patients with metastatic disease. But this combination did not have a significant effect on survival in comparison with other combinations $(\mathrm{P}=0.65)$. The second most frequently used combination was the docetaxel/cisplatin combination. A significant effect of gemcitabine or taxane use on survival was not detected $(\mathrm{P}=0.54)$. The cisplatin or carboplatin combinations did not show a significant effect on survival in both metastatic and non-metastatic patients. The survival curves of treatment modalities in non-metastatic and metastatic patients are shown in Figure 1 and Figure 2, respectively.

The median follow-up period was $4(1-55)$ months. PFS was 4 months (95\% CI: 2.1 - 5.9 months) in non-metastatic patients and 3 months (95\% CI: 2.6 - 3.3 months) in metastatic patients. OS was 4 months (95\% CI: 2.9 - 5.1 months).
OS rates for 1 and 2 years were $10 \%$ and $2 \%$. Parameters that might have an effect on survival are summarized in Table 3.

\section{Discussion}

Gerontologists classify aging as young-old age between 65 and 74 years, middle-old age between 75 and 84 years, and oldest old age above 85 years $[17,18]$. Life expectancy is limited in this age group. The question whether a patient will die from cancer or from other natural causes should be answered. Another problem is the side effects related to treatment, which may cause deterioration of the present condition of the patient during therapy. ADL, IADL [5], and the CGA [6-9] are systems developed to predict the performance and chemotherapy tolerance of elderly patients. The most appropriate patients

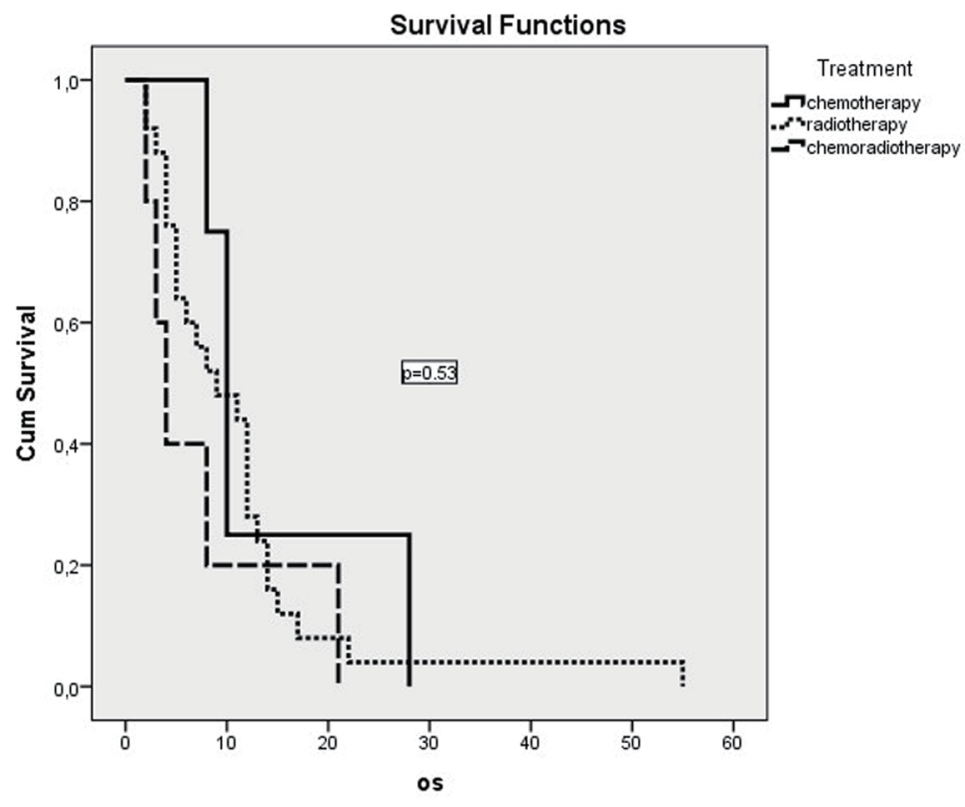

Figure 1. OS curves of non-metastatic patients who had received treatment. 


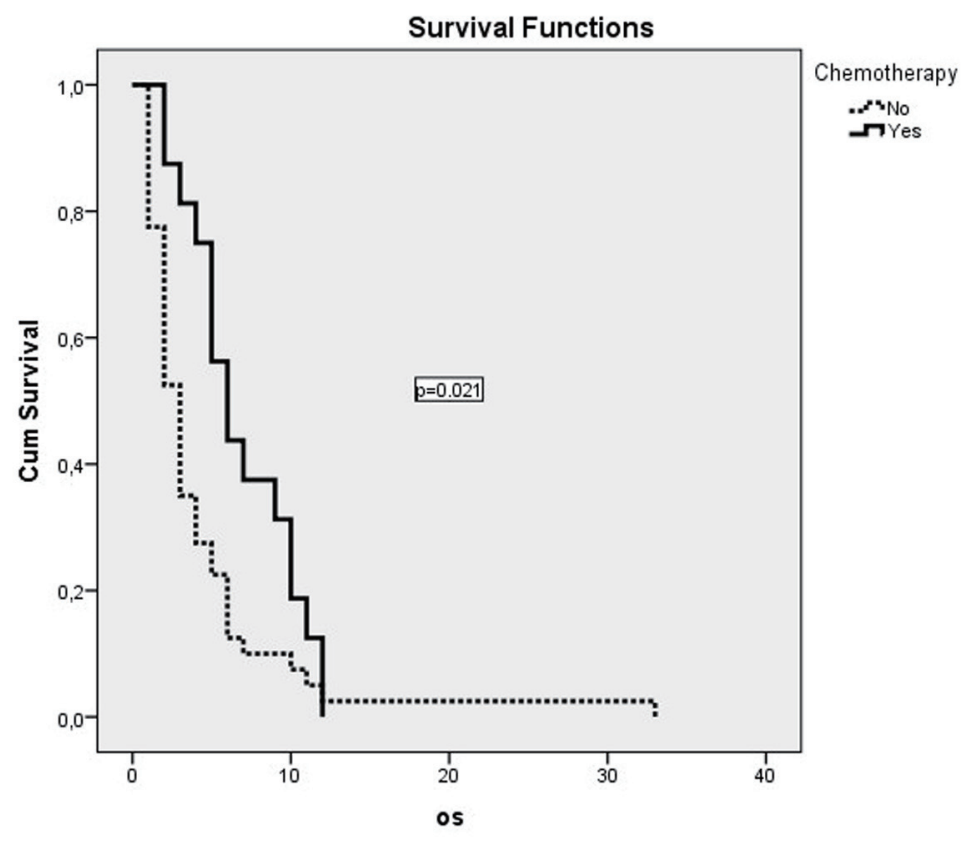

Figure 2. OS curves of metastatic patients who had received chemotherapy.

may be selected with the help of these systems.

There are studies showing the absence of a difference in survival of elderly ( $>70$ years) and younger patients with stage I, II and some selected IIIA NSCLC, who received surgical treatment $[19,20]$. Gray et al have shown a positive effect of surgical treatment on survival in patients older than 66 years with NSCLC [21]. We did not observe a significant difference in OS in the three patients who were surgically treated in our study $(\mathrm{P}=0.28)$. This finding may be explained by the limited number of surgical patients in our study. On the other hand, an OS of 28 months observed in the 75 -year-old patient with stage IIIA disease who had received pneumonectomy and adjuvant chemotherapy is an important finding. Although surgical treatment is controversial in the medical literature [20,22], surgery should be considered in appropriate middle-aged patients.

Adjuvant chemotherapy is controversial. Pepe et al have reported a positive effect of chemotherapy on OS in patients aged $>65$ years, and a negative effect on OS in patients aged $>75$ years [23]. Patients over 70 years who were administered chemotherapy were reported to be able to receive lower doses of cisplatin, also with fewer chemotherapy cycles [24].

As in our study, most of the old patients are not candidates for surgery, due to the presence of co-morbidities or advanced stage disease. There are studies that have shown the feasibility of definitive radiotherapy or sequential radiotherapy with chemotherapy in such patients [25-28]. Although chemoradiotherapy is more toxic in comparison to younger patients, it may also be used in elderly patients [29-32]. But caution is required for patient selection for chemoradiotherapy. In our study, although not statistically significant, the shortest survival was observed in patients who had received chemoradiotherapy, which was 4 months (95\% CI: 1.8 - 6.1 months, $\mathrm{P}=0.7$ ).

Most of the elderly patients are diagnosed at metastatic stages. The ratio of metastatic disease was $55.8 \%$ in our study. Both the short OS in metastatic NSCLC and the short life expectancy in this age group cause reservations for chemotherapy of metastatic patients. But there are studies reporting improvement in survival with vinorelbin as a single agent in comparison with BSC in patients older than 70 years with metastatic NSCLC, and a decrease in complaints due to the tumor [33]. Later, positive effects of docetaxel and paclitaxel in this patient group were also reported [34].

Should chemotherapy regimens contain a single agent or dual agents? In a phase III study, Quoix et al administered a weekly dual regimen including paxlitaxel and carboplatin to patients 70 - 89 years of age, and vinorelbin or gemcitabine as a single agent to other groups [35]. The median OS was 10.3 months in the dual agent chemotherapy group and 6.2 months in the single agent group, with a statistically significant difference $(\mathrm{P}<0.001)$. As a result of this study, a combination regimen including weekly carboplatin and paclitaxel in middle-old age patients was recommended as first line treatment. Langer et al reported that chemotherapy regimens including cisplatin may be used even in elderly patients [36]. Our study seemingly indicates that combination chemotherapy regimens were preferred. The number of courses was between 2 and 6 . Toxicity and side effects were also more frequently encountered. In our study, chemotherapy administered to metastatic patients was found to be a factor that has a statistically significant effect on survival $(\mathrm{P}<0.04)$.

The use of cisplatin or carboplatin in dual chemotherapy regimens in this age group is important. There are studies in the medical literature that have shown no difference between cisplatin and carboplatin on OS when administered to patients over 70 years of age $[37,38]$. Blanchard et al have reported negative effects of cisplatin use in elderly patients [39]. Our 
study was conducted with patients in the $75-85$ year old group. No difference between the effects of cisplatin or carboplatin use on OS was detected in these patients $(\mathrm{P}=0.39)$.

Old patients represent a special population. An elderly patient with metastatic lung cancer may be considered as "already doomed for death", but as was the case in our study with the 80 -year-old patient with stage IIIB NSCLC, a survival of 55 months may be obtained with an appropriate treatment after a sound evaluation and appropriate patient selection.

\section{Acknowledgement}

None.

\section{Disclosure}

No authors report any conflict of interest.

\section{References}

1. Vora N, Reckamp KL. Non-small cell lung cancer in the elderly: defining treatment options. Semin Oncol. 2008;35(6):590-596.

2. Parkin DM. Global cancer statistics in the year 2000 . Lancet Oncol. 2001;2(9):533-543.

3. Silverberg E, Lubera JA. Cancer statistics, 1988. CA Cancer J Clin. 1988;38(1):5-22.

4. Earle CC, Neumann PJ, Gelber RD, Weinstein MC, Weeks JC. Impact of referral patterns on the use of chemotherapy for lung cancer. J Clin Oncol. 2002;20(7):17861792.

5. Maestu I, Munoz J, Gomez-Aldaravi L, Esquerdo G, Yubero A, Torregrosa MD, Romero R. Assessment of functional status, symptoms and comorbidity in elderly patients with advanced non-small-cell lung cancer (NSCLC) treated with gemcitabine and vinorelbine. Clin Transl Oncol. 2007;9(2):99-105.

6. Extermann M, Hurria A. Comprehensive geriatric assessment for older patients with cancer. J Clin Oncol. 2007;25(14):1824-1831.

7. Mohile SG, Klepin HD, Rao AV. Considerations and controversies in the management of older patients with advanced cancer. Am Soc Clin Oncol Educ Book. 2012:321328.

8. Wildiers H, Kenis C. Comprehensive geriatric assessment (CGA) in older oncological patients: Why and how. J Geriatr Oncol. 2012;3:174-176.

9. Extermann M. Integrating a geriatric evaluation in the clinical setting. Semin Radiat Oncol. 2012;22(4):272276.

10. Chemotherapy in non-small cell lung cancer: a metaanalysis using updated data on individual patients from 52 randomised clinical trials. Non-small Cell Lung Cancer Collaborative Group. BMJ. 1995;311(7010):899-909.

11. Rapp E, Pater JL, Willan A, Cormier Y, Murray N, Evans WK, Hodson DI, et al. Chemotherapy can prolong surviv- al in patients with advanced non-small-cell lung cancer-report of a Canadian multicenter randomized trial. J Clin Oncol. 1988;6(4):633-641.

12. Gridelli C. The ELVIS trial: a phase III study of singleagent vinorelbine as first-line treatment in elderly patients with advanced non-small cell lung cancer. Elderly Lung Cancer Vinorelbine Italian Study. Oncologist. 2001;6(Suppl 1):4-7.

13. Frasci G, Lorusso V, Panza N, Comella P, Nicolella G, Bianco A, DeCataldis G, et al. Gemcitabine plus vinorelbine yields better survival outcome than vinorelbine alone in elderly patients with advanced non-small cell lung cancer. A Southern Italy Cooperative Oncology Group (SICOG) phase III trial. Lung Cancer. 2001;34(1):65-69.

14. Gridelli C, Perrone F, Gallo C, Cigolari S, Rossi A, Piantedosi F, Barbera S, et al. Chemotherapy for elderly patients with advanced non-small-cell lung cancer: the Multicenter Italian Lung Cancer in the Elderly Study (MILES) phase III randomized trial. J Natl Cancer Inst. 2003;95(5):362-372.

15. Comella P, Frasci G, Carnicelli P, Massidda B, Buzzi F, Filippelli G, Maiorino L, et al. Gemcitabine with either paclitaxel or vinorelbine vs paclitaxel or gemcitabine alone for elderly or unfit advanced non-small-cell lung cancer patients. Br J Cancer. 2004;91(3):489-497.

16. Hainsworth JD, Spigel DR, Farley C, Shipley DL, Bearden JD, Gandhi J, Ann Houston G, et al. Weekly docetaxel versus docetaxel/gemcitabine in the treatment of elderly or poor performance status patients with advanced nonsmall cell lung cancer: a randomized phase 3 trial of the Minnie Pearl Cancer Research Network. Cancer. 2007;110(9):2027-2034.

17. WHO (1972). Psychogeriatric, report of a WHO Scientific Group, Technical Reports Series 507, Geneva. Cited in Davise AM. Epidemiology. 185;14(1):9-21.

18. WHO (1984). The uses of epidemiology in the study of the elderly. WHO, Technical Reports Series 706, Geneva. 8-9.

19. Sterlacci W, Stockinger R, Schmid T, Bodner J, Hilbe W, Waldthaler C, Oberaigner W, et al. The elderly patient with surgically resected non-small cell lung cancer--a distinct situation? Exp Gerontol. 2012;47(3):237-242.

20. Rivera C, Falcoz PE, Bernard A, Thomas PA, Dahan M. Surgical management and outcomes of elderly patients with early stage non-small cell lung cancer: a nested casecontrol study. Chest. 2011;140(4):874-880.

21. Gray SW, Landrum MB, Lamont EB, McNeil BJ, Jaklitsch MT, Keating NL. Improved outcomes associated with higher surgery rates for older patients with early stage nonsmall cell lung cancer. Cancer. 2012;118(5):14041411.

22. Chambers A, Routledge T, Pilling J, Scarci M. In elderly patients with lung cancer is resection justified in terms of morbidity, mortality and residual quality of life? Interact Cardiovasc Thorac Surg. 2010;10(6):1015-1021.

23. Pepe C, Hasan B, Winton TL, Seymour L, Graham B, Livingston RB, Johnson DH, et al. Adjuvant vinorelbine and cisplatin in elderly patients: National Cancer Institute of Canada and Intergroup Study JBR.10. J Clin Oncol. 
2007;25(12):1553-1561.

24. Fruh M, Rolland E, Pignon JP, Seymour L, Ding K, Tribodet $\mathrm{H}$, Winton $\mathrm{T}$, et al. Pooled analysis of the effect of age on adjuvant cisplatin-based chemotherapy for completely resected non-small-cell lung cancer. J Clin Oncol. 2008;26(21):3573-3581.

25. Hayakawa K, Mitsuhashi N, Katano S, Saito Y, Nakayama Y, Sakurai H, Akimoto T, et al. High-dose radiation therapy for elderly patients with inoperable or unresectable non-small cell lung cancer. Lung Cancer. 2001;32(1):8188.

26. Furuse K, Fukuoka M, Kawahara M, Nishikawa H, Takada Y, Kudoh S, Katagami N, et al. Phase III study of concurrent versus sequential thoracic radiotherapy in combination with mitomycin, vindesine, and cisplatin in unresectable stage III non-small-cell lung cancer. J Clin Oncol. 1999;17(9):2692-2699.

27. Zatloukal P, Petruzelka L, Zemanova M, Havel L, Janku F, Judas L, Kubik A, et al. Concurrent versus sequential chemoradiotherapy with cisplatin and vinorelbine in locally advanced non-small cell lung cancer: a randomized study. Lung Cancer. 2004;46(1):87-98.

28. Curran WJ, Jr., Paulus R, Langer CJ, Komaki R, Lee JS, Hauser S, Movsas B, et al. Sequential vs. concurrent chemoradiation for stage III non-small cell lung cancer: randomized phase III trial RTOG 9410. J Natl Cancer Inst. 2011;103(19):1452-1460.

29. Langer CJ, Hsu C, Curran W, Sause WT, Swann RS, Langer CJ, Byhardt RW et al. Elderly patients with locally advanced non-small cell lung cancer (LA-NSCLC) benefit from combined modality therapy: secondary analysis of Radiation Therapy Oncology Group (RTOG) 9410. Proc Am Soc Clin Oncol. 2002;21:Abstr 1193.

30. Schild SE, Stella PJ, Geyer SM, Bonner JA, McGinnis WL, Mailliard JA, Brindle J, et al. The outcome of combined-modality therapy for stage III non-small-cell lung cancer in the elderly. J Clin Oncol. 2003;21(17):32013206.

31. Hardy D, Liu CC, Cormier JN, Xia R, Du XL. Cardiac toxicity in association with chemotherapy and radiation therapy in a large cohort of older patients with non-smallcell lung cancer. Ann Oncol. 2010;21(9):1825-1833.

32. Semrau S, Bier A, Thierbach U, Virchow C, Ketterer P, Klautke G, Fietkau R. 6-year experience of concurrent radiochemotherapy with vinorelbine plus a platinum compound in multimorbid or aged patients with inoperable non-small cell lung cancer. Strahlenther Onkol. 2007;183(1):30-35.

33. Effects of vinorelbine on quality of life and survival of elderly patients with advanced non-small-cell lung cancer. The Elderly Lung Cancer Vinorelbine Italian Study Group. J Natl Cancer Inst. 1999;91(1):66-72.

34. Ramalingam SS, Khuri FR. The role of the taxanes in the treatment of older patients with advanced stage non-small cell lung cancer. Oncologist. 2009;14(4):412-424.

35. Quoix E, Zalcman G, Oster JP, Westeel V, Pichon E, Lavole A, Dauba J, et al. Carboplatin and weekly paclitaxel doublet chemotherapy compared with monotherapy in elderly patients with advanced non-small-cell lung cancer: IFCT-0501 randomised, phase 3 trial. Lancet. 2011;378(9796):1079-1088.

36. Langer CJ, Manola J, Bernardo P, Kugler JW, Bonomi P, Cella D, Johnson DH. Cisplatin-based therapy for elderly patients with advanced non-small-cell lung cancer: implications of Eastern Cooperative Oncology Group 5592, a randomized trial. J Natl Cancer Inst. 2002;94(3):173-181.

37. Kelly K, Giarritta S, Hayes S. Should older patients receive combination chemotherapy for advanced stage non-small cell lung cancer? An analysis of Southwest Oncology trials 9509 and 9308. Proc Am Soc Clin Oncol. 2001;20:A-1313; 329a.

38. Langer C, Vangel M, Schiller J. Age-specific subanalysis of ECOG 1594: fit elderly patients (70-80 yrs) with NSCLC do as well as young pts $(<70)$. Lung Cancer. 2003;41:17.

39. Blanchard EM, Moon J, Hesketh PJ, Kelly K, Wozniak AJ, Crowley J, Gandara D. Comparison of platinumbased chemotherapy in patients older and younger than 70 years: an analysis of Southwest Oncology Group Trials 9308 and 9509. J Thorac Oncol. 2011;6(1):115-120. 